\title{
EXPLOSION OF THE BOUNDARY LAYER UPON ENTRY OF SPACECRAFT INTO DENSE LAYERS OF THE EARTH'S ATMOSPHERE
}

\author{
Leonid I. Gretchikhin \\ Belarusian State Academy of Communications, \\ Minsk, Republic of Belarus, \\ e-mail: gretchihin@yandex.ru, \\ ORCIDiD: 1 https://orcid.org/0000-0002-5358-9037
}

DOI: 10.5937/vojtehg68-28605; https://doi.org/10.5937/vojtehg68-28605 FIELD: Mechanical engineering, Aerodynamics
ARTICLE TYPE: Original scientific paper

\begin{abstract}
:
Introduction/purpose: $A$ supersonic flow around a sphere with a radius of $1 \mathrm{~m}$ at altitudes of 80 to $40 \mathrm{~km}$ was analysed.

Methods: The descent trajectory at the first cosmic velocity, similar to that of the Soyuz spacecraft with a duralumin structure without thermal protection, was taken into consideration.
\end{abstract}

Results: For the gas between the shock wave front and the surface of the descending spacecraft, data were obtained on the increase in density, pressure, and temperature behind the shock wave front as well as the shift of the shock wave from the surface of the descending spacecraft. The effective temperature of the shock-heated gas reaches its maximum value of $7340 \mathrm{~K}$ at an altitude of $60 \mathrm{~km}$. At altitudes of 80 and $40 \mathrm{~km}$, the effective temperature is $7000 \mathrm{~K}$ and $6400 \mathrm{~K}$, respectively. Based on the obtained data on the thermodynamic state of the gas behind the shock wave every $10 \mathrm{~km}$, calculations were made of energy fluxes to the surface of the spacecraft for convective and radiative heat transfer, as well as for the impact of electrons produced due to ionization of negative ions. Radiative heat transfer has proven to be the most significant. The burning mechanism of negative ions of triatomic molecules of aluminium with the formation of $\mathrm{A} / \mathrm{O}$ molecules was determined, and data on pressure rise in the boundary layer on the spacecraft surface were obtained. At all considered altitudes, the pressure rises instantly: to $1.06 \times 10^{10} \mathrm{~Pa}$ at an altitude of $80 \mathrm{~km}, 5.3 \times 10^{9} \mathrm{~Pa}$ at an altitude of $60 \mathrm{~km}$, and reaches the maximum value of $5.5 \times 10^{10} \mathrm{~Pa}$ and an altitude of $40 \mathrm{~km}$. A pressure of $10^{9}$ to $10^{10} \mathrm{~Pa}$ arises during explosion of various explosives. The energy flux reaches the spacecraft surface between explosions. At the moment of explosion, shock waves develop in the atmosphere surrounding the surface of the descending spacecraft, and compressive waves 
develop in the entire structure of the spacecraft. The descending spacecraft cracks, and its entire structure breaks down into parts. The area of interaction increases sharply, and each subsequent explosion has a greater intensity and size. As a result, the last most intense explosion occurs at an altitude of approx. $40 \mathrm{~km}$, after which individual fragments of the spacecraft fall to Earth.

Conclusion: The exploration of space with flight to other planets is possible only after a thorough study of explosive processes taking place on the surface of the spacecraft descending on other planets, and especially on Earth.

Keywords: explosion of explosives, supersonic motion, convective heat transfer, radiative heat transfer, electron flux effects, negative ions.

\section{Introduction}

During the exploration of space, there was a problem of retrieving spacecraft reentering the Earth's atmosphere at the first and, especially, the second cosmic velocity. The nature of the flow around flying objects at different altitudes is well defined. At very high altitudes starting from approx. $120 \mathrm{~km}$ and above, the flow around moving bodies corresponds to the free-molecular regime (Gretchikhin, 1986), (Gretchikhin, 2003). At altitudes below $120 \mathrm{~km}$ and up to approx. $100 \mathrm{~km}$, the transition flow regime takes place. Starting from altitudes below $100 \mathrm{~km}$, the continual flow regime (i.e. the supersonic flight) takes place. In this flight regime, strong shock waves are formed with a sharp increase in hightemperature gas on the spacecraft surface, causing a noticeable heating of the surface of the descending spacecraft. Previously, it was assumed that heating of the surface occurs due to intense convective and radiative heat transfer.

Various heat-barrier materials were used to protect descending spacecraft from the effects of the emerging heat fluxes. For the first cosmic velocity, pyrolytic graphite with a thickness up to $5 \mathrm{~cm}$ was used in the front hemisphere. 1) It was assumed that the temperature of the shock-compressed gas does not exceed $3500-4000 \mathrm{~K}$. The burning behaviour of the thermal-protective coating at such temperatures could be studied in laboratory conditions. These studies were carried out, and a full analysis of the results taking into account the emission of negative ions from the surface was performed (Gretchikhin, 1986).

1) This thickness was sufficient, since the thermal-protective coating burned out no more than $3 \mathrm{~cm}$. 
In the supersonic flow regime, a mixture of air heated by the shock wave with debris of the thermal-protective coating emerges between the shock wave and the surface of the descending spacecraft. The chemical reactions taking place in such a mixture were beyond our vision.

With the development of rocket technology, intensive exploration of space began. A spacecraft re-entering the Earth's atmosphere at the first cosmic velocity has a speed of approx. $7.5 \mathrm{~km} / \mathrm{s}$, and at the second cosmic velocity - approx. $11.2 \mathrm{~km} / \mathrm{s}$ or greater. Such flight conditions lead to the emergence of strong shock waves. The air behind the shock wave heats up to temperatures above $4000 \mathrm{~K}$. The burning behaviour of the thermal-protective coating under such conditions remained unclear. The burning behaviour of the thermal-protective coating is even more complex when a spacecraft enters dense atmospheric layers at the second or greater cosmic velocity. In this case, the destruction of the thermal-protective coating will be more intense. How can a descending spacecraft be safely retrieved under such conditions? The temperature increases significantly in the emerging shock wave. Intense convective and radiative heat transfers occur. Without taking into account the effects of negative ions, the performed theoretical calculation has allowed to establish that the thickness of the burn-out of the thermalprotective coating during the continuous movement of the burning front can be approx. $2 \mathrm{~cm}$. This result was shocking. Then the effects of negative ions had to be taken into account.

Ionization of negative ions produces an intense flux of electrons to the surface of the thermal-protective coating, and in combination with the radiative and convective heat flux, such a net energy flux is formed that an explosion of the surface layer occurs. At this moment, heat stops coming to the surface of the spacecraft. Specific evaluations showed that the thermal-protective coating at the second cosmic velocity should burn less when compared to the first cosmic velocity. After a circumlunar flight followed by the descent of the spacecraft at the second cosmic velocity, the thickness of the burned-out thermal-protective coating turned out to be approx. $2 \mathrm{~cm}$, i.e. less than at the first cosmic velocity with a burn-out thickness of approx. $3 \mathrm{~cm}$.

At the second cosmic velocity, heat-barrier materials do not burncontinuously, but with separate explosive pulses, which was proven demonstratively during the first studies of the effect of laser radiation (Gretchikhin\&Minko, 1967) as well as with arc and spark discharge 
cathode flares (Gretchikhin\&Minko, 1967) and (Gretchikhin\&Tyunina, 1967). The results of these studies are shown in Fig. 1.



Figure 1 - Destruction pattern: a) electric arc discharge between carbon electrodes and explosive processes at the cathode at a power of $1.3 \cdot 10^{9} \mathrm{~W} / \mathrm{m}^{2}$;

b) explosive processes during exposure of laser radiation with a power of $5 \cdot 10^{11} \mathrm{~W} / \mathrm{m}^{2}$ on: copper (top) and aluminium (bottom)

Puс. 1 - Схема разрушения: а) дуговой разряд между угольными электродами и взрывные процессы на катоде мощностью $1.3 \cdot 10^{9} \mathrm{~W} / \mathrm{m}^{2}$;

б) взрывные процессы при воздействии лазерного излучения мощностью $5 \cdot 10^{11} \mathrm{~W} / \mathrm{m}^{2}$ :

медь (сверху) и алюминий (снизу)

Слика 1 - Образац деструкције: а) пражњење електричног лука између електрода угљеника и експлозивни процеси на катоди при снази $1,3 \times 10^{9} \mathrm{~W} / \mathrm{m}^{2}$; б) експлозивни процеси током излагања ласерском зрачењу снаге $5 \times 10^{11} \mathrm{~W} / \mathrm{m}^{2}$ y бакру (горе) и алуминијуму (доле)

Experimental results indicate that the destruction of a solid at energy fluxes greater than $10^{9} \mathrm{~W} / \mathrm{m}^{2}$ occurs in the form of successive explosions. The frequency of explosions at the cathode in the arc discharge between carbon electrodes is approx. $150 \mathrm{kHz}$ with an energy flux of $1.3 \cdot 10^{9} \mathrm{~W} / \mathrm{m}^{2}$ (Gretchikhin\&Tyunina, 1967), and approx. $290 \mathrm{kHz}$ when aluminium is exposed to laser radiation with an effective absorbed energy flux of $4.2 \cdot 10^{10} \mathrm{~W} / \mathrm{m}^{2}$ (Gretchikhin\&Minko, 1967).

Thus, the gaseous products of destruction of the surface layer of the descending spacecraft mix with the ambient environment and react with air molecules. Depending on the type of the chemical reaction (endothermic or exothermic), additional cooling or heating of the heated air behind the shock wave takes place in the frontal part of the spacecraft. Exothermic reactions with the release of energy are

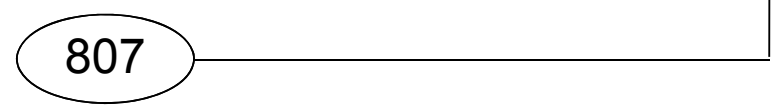


especially dangerous. Therefore, let us have a closer look at the dynamics of the destruction of the surface of the descending spacecraft determining the number of atoms and molecules that mix with the heated air behind the shock wave, and how much energy is released in various exothermic reactions. This posed the task of finding out what energy is absorbed by a moving object and how this affects the flight dynamics of the descending spacecraft. It is important to determine what processes occur in the shock-compressed gas area in the frontal part of space objects descending at the first and especially at the second cosmic velocity. In this work, we will consider in detail a spacecraft without thermal-protective coating descending at the first cosmic velocity ${ }^{2}$. In order to achieve this objective, the following tasks must be solved:

- Determining the heating dynamics of the shock-compressed gas and the effective temperature of atoms and molecules in the area between the shock wave and the spacecraft surface at altitudes of 40 to $80 \mathrm{~km}$, where strong shock waves are formed,

- Developing an impact theory of convective heat transfer,

- Considering the structure of the exposed surface in radiative heat transfer

- Developing a theory of energy transfer by electrons produced due to the ionization of negative ions, and

- Performing an analysis of the explosive processes taking place when various space objects enter dense layers of the Earth's atmosphere.

Now, let us consider these objectives one by one.

\section{Effective temperature of the air compressed by the shock wave}

When a spacecraft descends from the orbit, a shock wave begins to form at an altitude of approx. $100 \mathrm{~km}$. As the altitude decreases, the speed increases slightly, and then drops sharply from an altitude of $40 \mathrm{~km}$. The change in flight speed with altitude for a descending Soyuz series spacecraft is given in Table 1.

${ }^{2}$ ) These conditions correspond to the re-entry conditions of the long-term orbital station MIR-1. 
Table 1 - Parameters of the air behind the shock wave at the first cosmic velocity

Таблица 1 - Параметры воздуха за ударной волной при первой космической скорости

Табела 1 - Параметри ваздуха иза ударног таласа при првој космичкој брзини

\begin{tabular}{|l|l|l|l|l|l|}
\hline \multirow{2}{*}{ Parameters } & \multicolumn{4}{|l|}{ Altitude, $\mathrm{km}$} & \multicolumn{4}{l|}{} \\
\cline { 2 - 6 } & 40 & 50 & 60 & 70 & 80 \\
\hline $\begin{array}{l}\text { First cosmic velocity, } \\
\text { Mach }\end{array}$ & 22.35 & 23.82 & 25.34 & 25.80 & 26.42 \\
\hline Density, $\rho / \rho_{\infty}$ & 5.940 & 5.947 & 5.954 & 5.955 & 5.957 \\
\hline Pressure, $P / P_{\infty}$ & 584 & 663 & 750.1 & 777.6 & 815 \\
\hline $\begin{array}{l}\text { Shock wave shift } \\
\text { distance, } m\end{array}$ & 0.112 & 0.112 & 0.1119 & 0.1118 & 0.1118 \\
\hline $\begin{array}{l}\text { Temperature at the } \\
\text { wave front, } K\end{array}$ & 25746 & 27532 & 29357 & 28595 & 28057 \\
\hline $\begin{array}{l}\text { Temperature of the } \\
\text { shock-compressed } \\
\text { gas, } K\end{array}$ & 6437 & 6883 & 7339 & 7149 & 7014 \\
\hline $\begin{array}{l}\text { Effective temperature } \\
\text { of the compressed gas, } \\
K\end{array}$ & 6434 & 6880 & 7337 & 7146 & 7012 \\
\hline $\begin{array}{l}\text { Convective heat } \\
\text { transfer, } W / m^{2}\end{array}$ & $2.0110^{7}$ & $5.4810^{6}$ & $2.2410^{6}$ & $3.8510^{5}$ & $5.5710^{4}$ \\
\hline Penetration depth, $m$ & $7.51 \cdot 10^{-2}$ & $1.98 \cdot 10^{-2}$ & $7.81 \cdot 10^{-3}$ & $1.36 \cdot 10^{-3}$ & $2.00 \cdot 10^{-4}$ \\
\hline $\begin{array}{l}\text { Radiative heat transfer, } \\
W / m^{2}\end{array}$ & $4.8610^{6}$ & $6.3510^{6}$ & $8.2110^{6}$ & $7.3910^{6}$ & $6.85 \cdot 10^{6}$ \\
\hline $\begin{array}{l}\text { Electron flux heat } \\
\text { transfer, } W / m^{2}\end{array}$ & $2.56 \cdot 10^{7}$ & $6.9810^{6}$ & $2.8510^{6}$ & $4.9010^{5}$ & $7.09 \cdot 10^{4}$ \\
\hline $\begin{array}{l}\text { Pressure in the } \\
\text { boundary layer, } P a\end{array}$ & $5.485 \cdot 10^{10}$ & $1.62 \cdot 10^{10}$ & $5.938 \cdot 10^{9}$ & $7.088 \cdot 10^{9}$ & $1.059 \cdot 10^{10}$ \\
\hline $\begin{array}{l}\text { Energy released on the } \\
\text { surface, } J\end{array}$ & $4.477 \cdot 10^{6}$ & $1.092 \cdot 10^{6}$ & $1.096 \cdot 10^{5}$ & $1.367 \cdot 10^{5}$ & $1.921 \cdot 10^{5}$ \\
\hline
\end{tabular}

Flight speeds are much higher than the speed of sound. In this case, the density, pressure and temperature of the gas in the shock wave can be determined by the formulas (Gretchikhin et al, 2012).

$$
\rho=\rho_{\infty}\left(\frac{\gamma-1}{\gamma+1}+\frac{2}{\gamma+1} \frac{1}{M^{2}}\right)^{-1} ; \rho=\rho_{\infty}\left(1+\frac{2_{\gamma}}{\gamma+1} M^{2}\right) ; T=T_{0} \frac{\rho_{\infty}}{\rho} \frac{P}{P_{\infty}}
$$

where $\gamma$ is the ratio of the specific heat capacities of the gas at constant volume and constant pressure; and $M$ is the Mach number. Specific calculations for a sphere with a radius of $1 \mathrm{~m}$ at different altitudes are given in Table 1. At all altitudes, the temperature directly in the front 
of the shock wave is relatively high, comparable to high-power pulsed electric discharge. The shift distance of the shock wave from the nose of a hypersonic vehicle of a given geometry for a direct shock wave in the first approximation can be determined as follows: (Gretchikhin et al, 2012)

$$
\Delta=R \frac{\rho_{\infty}}{\rho}\left(1-\frac{\rho_{\infty}}{\rho}+\sqrt{\frac{8}{3}} \frac{\rho_{\infty}}{\rho}\right)^{-1}
$$

High temperature behind the direct shock wave causes significant heating of the air atmosphere. Diatomic molecules of nitrogen and oxygen dissociate instantly and completely. Since this requires energy, the temperature in the shock wave decreases.

The number of particles doubles. Also, the ionization of oxygen and nitrogen atoms takes place, which leads to a decrease in the adiabatic index. Taking into account the dissociation process, the temperature of the air behind the shock wave (Zeldovich\&Raizer, 2008) and (Kheiz\&Probstin, 1962) is:

$$
T_{B}=T_{0} \frac{\rho_{\infty}}{\rho} \frac{P}{P_{\infty}} \alpha
$$

At temperatures above $10,000 \mathrm{~K}$, nitrogen and oxygen molecules will dissociate completely, and then $\alpha=0.5$. As a result of ionization, the air temperature will decrease due to the formation of plasma. Then (Zeldovich\&Raizer, 2008) and (Kheiz\&Probstin, 1962)

$$
T_{\text {eff. }} \approx \frac{T_{B}}{3-\gamma}
$$

For dry air at a temperature of $2000 \mathrm{~K}$, the adiabatic index is $\gamma=1.088$

For higher temperatures, we can assume that $\gamma \approx 1$.

The results of calculation according to (4) are shown in Table 1. The temperature of the shock-compressed gas is sufficiently high, and such a gas should be considered as plasma. Charged particles are produced in plasma as a result of the ionization of predominantly negative ions. Therefore, thermal energy is transferred to the surface of the descending spacecraft due to convective and radiative heat transfer, as well as due to the flow of electrons when passing through the electrical double layer. 
The input data on the energies of dissociation of diatomic molecules, detachment of atoms in triatomic molecules and electron affinity for aluminium are given in Table 2.

Table 2 - Energy of dissociation and detachment of an electron in a negative aluminium ion

Таблица 2 - Энергия диссоциации и отрыва электрона в отрицательном ионе алюминия

Табела 2 - Енергија дисоцијације и одвајање електрона у негативном јону алуминијума

\begin{tabular}{|l|l|l|}
\hline \multirow{2}{*}{$\begin{array}{l}\text { Atoms, } \\
\text { molecules }\end{array}$} & \multicolumn{2}{|l|}{ Energy, eV } \\
\cline { 2 - 3 } & dissociation & $\begin{array}{l}\text { Electron } \\
\text { detachment }\end{array}$ \\
\hline$A l_{3}^{-}$ & $\sim 0.406$ & $\sim 1.785$ \\
\hline$A l_{2}^{-}$ & 2.0 & 2.42 \\
\hline$A l^{-}(3 \mathrm{P})$ & - & 0.44 \\
\hline$A l^{-}(1 \mathrm{D} 2)$ & - & 0.33 \\
\hline$A l O_{-}$ & 5.14 & 3.6 \\
\hline$A l O_{2}^{-}$ & $\sim 2.51$ & 4.1 \\
\hline
\end{tabular}

The " " symbol means that this value is obtained by extrapolation

\section{Convective heat transfer}

In convective heat transfer, energy is transferred by the collision of heated gas particles with the surface of the spacecraft. Each solid is formed by an intercluster lattice structure.

The clusters themselves are formed by diatomic or triatomic molecules.

The structure of clusters of diatomic molecules with experimental confirmation is reported in (Gretchikhin et al, 2015a) and (Gretchikhin, 2008), of triatomic molecules - in (Gretchikhin et al, 2015b) and (Gretchikhin, 2008). Fig. 2.

Aluminium clusters are formed by triatomic molecules as shown in 


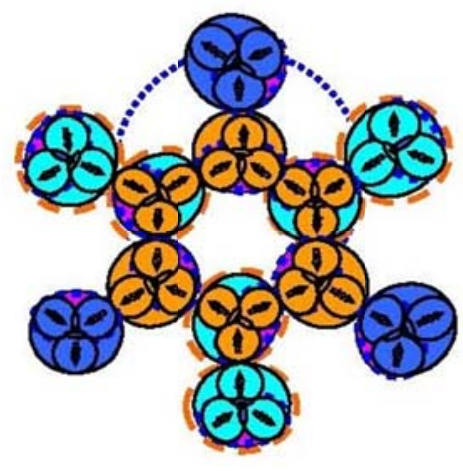

a)

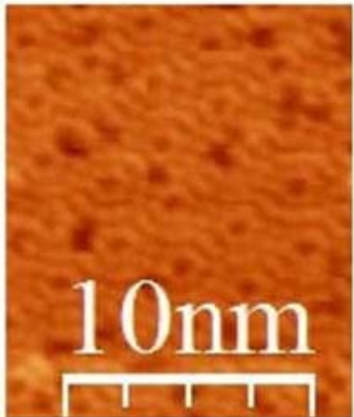

b)

Figure 2 - Cluster of triatomic molecules: a) theoretical calculation; b) experimental confirmation Puc. 2 - Кластер трехатомных молекул: a) теоретический расчет; б) экспериментальное измерение Слика 2 - Кластер триатомских молекула: а) теоријско израчунавање; б) експериментална потврда

The main cluster is highlighted in the center, and the highlighted triatomic molecules have broken bonds in diatomic molecules. As a result, some triatomic molecules in the center have an excess negative charge, and others - a positive charge. In Fig. 2, these molecules are shown in different colours. The clusters are flat and interact with each other by cohesion, and the solid resembles a layered cake. Clusters are formed as a result of the interaction of molecules of the first, second and third coordination layers (Gretchikhin et al, 2015b) and (Gretchikhin, 2008). The energy from the heated gas is transferred to the spacecraft surface by the collision of air molecules with the clusters of the solid. The thermal random velocity of the heated air

$$
v_{r}=\sqrt{\frac{8 k_{b} T_{a}}{\pi m_{a}}}
$$

where $k_{b}$ is the Boltzmann constant, $T_{a}$ is the temperature of the shockcompressed air and $m_{a}$ is the average weight of air molecules.

Only $1 / 6$ of air molecules collide directly with the surface. Molecules collide with clusters of the solid. In convective heat transfer, only the surface layer of cluster formations is excited. Clusters of aluminium are formed by triatomic molecules, producing a face-centered crystalline structure. Since there is a hollow in the centre of a cluster, which does not receive the impacts of external particles, only $9 / 10$ of the total flow of 
external particles acting on the surface of the spacecraft is received. The second coordination layer of the cluster is destroyed before the melting temperature is reached, and the first coordination layer is destroyed after the melting temperature is reached. Near the boiling temperature, the number of molecules in a cluster is approx - 6 (Gretchikhin et al, 2015b). When air molecules collide with clusters on the surface of a solid, the energy transfer ratio is (Gretchikhin, 2008).

$$
n=\frac{4 m_{a} m_{S}}{\left(m_{a}+m_{s}\right)^{2}}
$$

where $m_{b}$ is the weight of a solid cluster, and $m_{S}$ is the average effective mass of air molecules in the atomic form equal to approx. 29/2.

Taking into account (5) and (6), the convective energy flux to the solid surface is

$$
J_{c}=\frac{9}{120} \rho v \frac{3}{T} n
$$

where $\rho$ is the density of the air behind the shock front.

The energy consumption of a single molecule of the solid:

$$
E_{m}=\frac{10}{9} J_{c} \pi r_{m}^{2}
$$

The radius of a triatomic aluminium molecule $r_{m} \approx 2.155 r_{a}$, and $r_{a}$ is the radius of an atom of the solid, obtained by the radiographic method, approx. $1.43 \AA$. At each altitude, an aluminium object loses its weight to a depth

$$
d h=2 r_{a} \frac{E_{m}}{E_{\text {св. }}}
$$

where $E_{c b}$. is the molecular bond energy, which is determined by the boiling temperature. For aluminium, this value is $3.389 \cdot 10^{-20} \mathrm{~J}$. The results of the calculation of the depth of complete dissociation of the main clusters according to (13) are given in Table 1 . It takes only $3 / 4$ of the total heat flux in convective heat transfer. The remaining part of the convective energy flux is absorbed by intercluster hollows preventing the destruction of the solid (see Fig. 2b).

As a result of destruction, the total number of triatomic aluminium molecules is formed as negative ions

$$
N_{A I}=2 \pi r^{2} d h \frac{\rho_{A I}}{m_{b}}
$$

and the concentration of negative ions of triatomic aluminium molecules in the shock-compressed gas

$$
n_{A l}=\frac{N_{A I}}{2 \pi r^{2} d h}
$$

The temperature of the gas of triatomic aluminium molecules is equal to the boiling temperature, i.e. $T_{\text {кил. }}=2770 \mathrm{~K}$. 
The total number of air molecules in the shock-compressed air behind the shock wave

$$
N_{a}=2 \pi r^{2} d h p / m_{a}
$$

and the molecules are at the temperature determined according to (4).

The average effective temperature will be

$$
T_{\text {eff. }}=\left(\frac{T_{\text {boiling }} N_{A l}+T_{0} N_{a}}{N_{A l}+N_{a}}\right)
$$

At this temperature, the following aluminium combustion reactions occur:

$$
\begin{gathered}
A l_{3}+O \Leftrightarrow A l_{2}+A l O+e+1.134 \ni B ; A l_{2}+O \\
\Leftrightarrow A l+A l O+3.14 \ni B ; \\
A l+O \Leftrightarrow A l O+5.14 \ni B
\end{gathered}
$$

The total energy released during the complete combustion of triatomic aluminium molecules is $9.414 \mathrm{eV}$, and the energy of the electron gas corresponds to the effective temperature of the plasma determined according to (13). The electron gas produced ionizes negative ions of aluminium molecules by electron impact:

$$
\mathrm{Al}_{3}+e \Leftrightarrow \mathrm{Al}_{3}+2 e \text {. }
$$
1986)

In this case, the temperature of the electron gas is (Gretchikhin,

$$
T_{e}=0.55 \cdot I A \cdot 11600 \mathrm{~K}
$$

where IA is the ionization energy of plasma particles in $\mathrm{eV}$.

The electron gas produced from the ionization of negative ions is nonequilibrium. Consequently, the plasma of the shock-compressed gas at such temperatures of the electron gas and a sufficiently high temperature of the atomic gas has a very high radiation capacity, which is dangerous to eyesight. In this case, radiative heat transfer must be considered.

\section{Radiative heat transfer}

With a sufficiently dense plasma, the radiation of individual atoms and molecules from the inner layers is intensely absorbed inside the plasma, and thermal radiation can be considered as black body radiation, taking into account the emissivity factor. For evaluations, let us assume that the emissivity factor $\kappa=0.5$. Then

$$
J_{L}=K \sigma_{S} T_{\ni \phi \phi}^{4}
$$

where $\sigma_{S}=5.67 \cdot 10^{-8} \mathrm{Bm} \cdot \mathrm{M}^{-2} \mathrm{~K}^{-4}$ is the Stefan constant. 
The results of the obtained radiant energy fluxes at different altitudes are given in Table 1 . The energy flux in radiative heat transfer penetrates through the solid to the skin layer depth. If the solid receives external radiation, then the thickness of the skin layer can be determined according to the formula (Gretchikhin, 2016):

$$
\Delta r=\sqrt{\frac{\rho_{\ni}}{\pi f \mu}}
$$

where $f$ is the electromagnetic radiation frequency, $\mu$ is the magnetic permeability, and $\rho_{\ni}$ is the electrical conductivity of the solid.

In formula (18), the frequency of thermal radiation $f$ corresponds to the maximum of the radiation flux density distribution function per unit frequency interval according to the Planck formula. Therefore, the obtained specific values of the absorption thickness are much smaller than the thickness of the aluminium cluster. This means that all incident radiation is completely reflected from an aluminium surface with a closepacked structure (Fig. $2 b$ ). The absorption of the radiant flux takes place at defects of the crystalline structure and the centres of cluster formations. For an ideal surface, absorption occurs only by the centres of cluster formations and is approximately $1 / 10$, and as the surface transits to the liquid state, the ratio of the absorbed radiant flux energy increases, and the radiant flux contributes to the destruction of both a metal and a dielectric moving object.

With the emission of molecules with an electron affinity from the spacecraft surface, an electric double layer is formed. At some distance, negative ions are ionized, and the produced electrons, passing through the potential difference of the double electric layer, bombard the surface and additionally increase the energy flux to the spacecraft surface.

\section{Electron impact energy flow}

Negative ions from the aluminium surface are emitted in the form of triatomic molecules at the boiling temperature. The ionization of negative ions of aluminium molecules takes place due to the occurrence of reactions (14) and (15). Both reactions take place in the gas-vapour phase. As a result of the emission of negative ions from the aluminium surface, an electric double layer is formed. The potential difference in the electric double layer is determined by the molecular energy at the boiling temperature. For aluminium, the potential difference of the double layer

$$
\Delta U=\frac{k_{b} T_{\text {boiling }}}{e} \cdot B
$$



will be

The flux of the energy carried by electrons to the aluminium surface

$$
J_{e}=n_{A l}^{-} v_{e} k_{b} T_{\text {boiling }}
$$

and the total energy transferred to the surface by electron impact will be

$$
\Delta E_{2}=J_{e} 2 \pi r^{2} d h \text {. }
$$

The total energy to the metal surface of a solid entering dense atmospheric layers is the sum of convective, radiative and electronic heat transfer. The pressure that arises in the boundary layer is

$$
P=\frac{\Delta E}{2 \pi r^{2} \Delta l}
$$

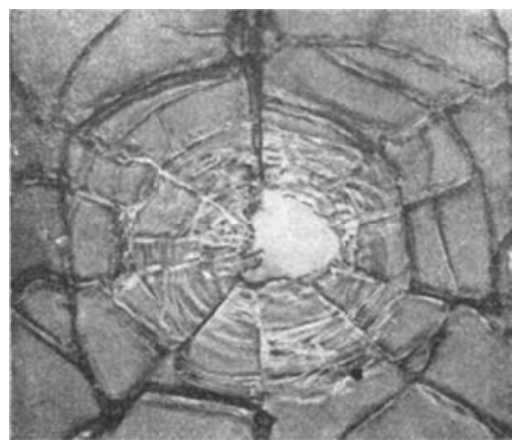

Figure 3 - Fracture pattern in a glass plate exposed to an explosion pressure of $2.8 \cdot 10^{9} \mathrm{~Pa}$

Puc. 3 - Изображение разрушения стеклянной пластины под давлением взрыва 2.8.10 $\mathrm{Pa}$

Слика 3 - Начин лома стаклене плоче изложене притиску експлозије од

$$
2,8 \times 10^{9} \mathrm{~Pa}
$$

The values of pressure arising in the boundary layer at different altitudes are given in Table 1. The obtained pressure values are typical for the explosion of explosives (Gretchikhin, 2008). The explosion in the boundary layer has such high intensity that the entire structure of the spacecraft breaks down into small parts. This process is shown in Fig. 3 (Gretchikhin, 2008). A sublimation spot appears in the centre of the explosion. An explosion on the surface of a solid causes not only sublimation, but also cracking of the entire array in the form of radial cracks, as well as a formation of cylindrical and spherical cracks inside the solid. Each explosion on the spacecraft surface causes an intensive sublimation of the flow of solid molecules, and, accordingly, blocks the flow of energy to the surface. As a result, a sequence of explosions occurs, causing breakdown of the solid monolith into separate small 
parts. At the same time, the effective interaction surface between the solid and the shock-compressed air increases. The magnitude of the explosion energy is increasing in succession. The explosion fire cloud also expands. Finally, small fragments of the spacecraft fall onto Earth. This was experimentally confirmed when the long-term orbital station MIR-1, with the main structure made of duralumin without a thermalprotective coating, entered dense atmospheric layers.

\section{Conclusion}

From these studies, the following wasconcluded:

1. For the descent trajectory of the Soyuz series spacecraft with the structure made of duralumin without a thermal-protective coating at altitudes of 80 to $40 \mathrm{~km}$, data were obtained on the increase in density, pressure and temperature behind the shock front, as well as the shift of the shock wave from the surface of the descending spacecraft.

2. The effective temperature of the shock-compressed gas reaches its maximum value of $7340 \mathrm{~K}$ at an altitude of $60 \mathrm{~km}$. At altitudes of 80 and $40 \mathrm{~km}$, it reaches $7000 \mathrm{~K}$ and $6400 \mathrm{~K}$, respectively.

3. Calculations were made of the energy fluxes to the surface of the spacecraft for every $10 \mathrm{~km}$ in the altitude range of 40 to $80 \mathrm{~km}$, for convective and radiative heat transfer, as well as for the impact of electrons produced due to the ionization of negative ions. Radiative heat transfer has proven to be the most significant.

4. The increase in pressure in the boundary layer at the spacecraft surface was calculated taking into account the burning of negative ions of triatomic molecules of aluminium with the formation of $\mathrm{AlO}$ molecules. At all considered altitudes, the pressure rises instantly to a value of $10^{9}$ to $10^{10} \mathrm{~Pa}$ and more, which is typical for explosion of various explosives. Each subsequent explosion produces shock waves in the surrounding atmosphere and compressive waves in the entire structure of the spacecraft. The descending spacecraft cracks, and its entire structure breaks down into parts. The area of interaction increases sharply, and each subsequent explosion has a greater intensity and size. After each explosion, the energy flux to the surface stops due to shielding for all types of heat transfer. After the dispersion of the explosion products, an intense flux of energy reappears on the surface of the descending 
spacecraft and a new explosion occurs. As a result, the last most intense explosion occurs at an altitude of approx. $40 \mathrm{~km}$, after which individual fragments of the spacecraft fall onto Earth. All of this was clearly observed during the reentry of the long-term orbital station MIR-1.

5. The situation is slightly better for spacecraft with thermal protection, but is still very dangerous. Descents must not be carried out at low g-forces. Even at the first cosmic velocity, the descent phase at an altitude of 80 to $40 \mathrm{~km}$ should be passed as quickly as possible.

6. When descending spacecraft and meteors enter the atmosphere at the second or greater cosmic velocity, the temperature of the shockcompressed gas reaches up to $15,000 \mathrm{~K}$. At such temperature, the intensity of explosion increases by one order of magnitude or more. This results in falling of small debris and even individual dust particles onto Earth, which was observed when the Chelyabinsk meteor entered the Earth's atmosphere. We must not hurry into manned space exploration. It is necessary to carefully analyze the situation, think and think again! The Tunguska and Chelyabinsk meteor events were a serious warning!

\section{References}

Gretchikhin, L.I. 1986. Neravnovesnoe opticheskoe izluchenie vozdushnyh i kosmicheskih letatel'nyh apparatov. Ph.D. thesis. Minsk, Belarus: Belarusian Polytechnic Institute (in Russian). (In the original: Гречихин, Л.И. 1986. Неравновесное оптическое излучение воздушных и космических летательных аппаратов. Докторская диссертация. Минск, Беларусь: Белорусский политехнический институт).

Gretchikhin, L.I. 2003. Vzaimodejstvie tverdogo tela s okruzhajushhej sredoj v rezhime svobodnomolekuljarnogo obtekanija (jeffekt Gretchikhina). In The First Belarusian Space Congress, Minsk, Belarus, pp.31-33, October 28-30 (in Russian). (In th eoriginal: Гречихин, Л.И. 2003. Взаимодействие твердого тела с окружающей средой в режиме свободномолекулярного обтекания (эффект Гречихина). В: Первый Белорусский космический конгресс, г. Минск, Беларусь, с.31-33, 28-30 октября).

Gretchikhin, L.I. 2008. Nanochasticy i nanotehnologii. Minsk, Belarus: Pravo i jekonomika (in Russian). (In the original: Гречихин, Л.И. 2008. Наночастицы и нанотехнологии. Минск, Беларусь: Право и экономика).

Gretchikhin, L.I. 2016. Osnovy radiosvjazi. Minsk, Belarus: National Library of Belarus (in Russian). (In the original: Гречихин, Л.И. 2016. Основы радиосвязи. Минск, Беларусь: Национальная библиотека Беларуси).

Gretchikhin, L.I., Laptsevich, A.A. \& Kuts, N.G. 2012. Ajerodinamika letatel'nyh apparatov. Minsk, Belarus: Pravo i ekonimka (in Russian). (In the original: Гречихин, Л.И., Лапцевич, А.А., Куць, Н.Г. 2012. Аэродинамика летательных аппаратов. Минск, Беларусь: Право и экономика). 
Gretchikhin, L.I., Latushkina, S.D., Komarovskaya, V.M. \& Shmermbekk, Yu. 2015a. Formation of a close-packed and cluster lattice structure of indium on a silicon surface. Strengthening Technologies and Coatings, 6, pp.3-12 (in Russian) [online]. Available at: http://www.mashin.ru/files/2015/up615_web1.pdf [Accessed: 20 September 2020]. (In the original: Гречихин, Л.И., Латушкина, С.Д., Комаровская, В.М., Шмермбекк, Ю. 2015а. Образование плотноупакованной и кластерной решеточной структуры индия на поверхности кремния. Упрочняющие технологии и покрытия, 6, с.3-12 [онлайн]. Доступно на: http://www.mashin.ru/files/2015/up615_web1.pdf [Дата посещения: 20 сентября 2020 г.]).

Gretchikhin, L.I., Latushkina, S.D., Komarovskaya, V.M. \& Shmermbekk, Yu. 2015b. The cluster structure of silicon and its surface construction. Strengthening Technologies and Coatings, 9, pp.5-10 (in Russian) [online]. Available at: http://www.mashin.ru/files/2015/up_0915_01-48_min.pdf [Accessed: 20 September 2020]. (In the original: Гречихин, Л.И., Латушкина, С.Д., Комаровская, В.М., Шмермбекк, Ю. 2015b. Кластерная структура кремния и конструкция его поверхности. Упрочняющие технологии и покрытия, 9, с.5-10 [онлайн]. Доступно на: http://www.mashin.ru/files/2015/up615_web1.pdf [Дата посещения: 20 сентября 2020 г.]).

Gretchikhin, L.I. \& Minko, L.Ya. 1967. Ob analogii fizicheskih processov protekajushhih $\mathrm{v}$ impul'snom razrjade i pri vozdejstvii koncentrirovannogo lazernogo izluchenija. Zhurnal tehnicheskoj fiziki, 37 (in Russian). (In the original: Гречихин, Л.И., Минько, Л.Я. 1967. Об аналогии фризических процессов протекающих в импульсном разряде и при воздействии концентрированного лазерного излучения. Журнал технической фризики, 37).

Gretchikhin, L.I. \& Tyunina, E.S. 1967. Study of arc discharge electrode flares. 1967. Physics and chemistry of materials treatment, 11(3), in Russian. (In the original: Гречихин, Л.И., Тюнина, Е.С. 1967. Исследование электродных фракелов дугового разряда. Физика и химия обработки материалов, 11(3)).

Kheiz, I.D. \& Probstin, R.F. 1962. Theory of hypersonic phenomena. Moscow: Foreign Languages Publishing House (translation into Russian). (In the original: Хейз, И.Д., Пробстин, Р.Ф. 1962.Теория гиперзвуковых явлений. Москва: Издательство иностранной литературы, переведено с английского).

Zeldovich, Ya.B. \& Raizer, Yu.P. 2008. Fizika udarnyh voln $i$ vysokotemperaturnyh gidrodinamicheskih javlenij: prakticheskoe posobie. Moscow: Fizmatlit (in Russian). ISBN: 978-5-9221-0938-3. (In the original: Зельдович, Я.Б., $\quad$ Райзер, Ю.П. 2008. Физика ударных волн и высокотемпературных гидродинамических явлений: практическое пособие. Москва: Физматлит. ISBN: 978-5-9221-0938-3). 


\section{ВЗРЫВ ПОГРАНИЧНОГО СЛОЯ ПРИ ВХОЖДЕНИИ ЛЕТАТЕЛЬНЫХ АППАРАТОВ В ПЛОТНЫЕ СЛОИ ЗЕМНОЙ АТМОСФЕРЫ}

Леонид И. Гречихин

Белорусская государственная академия связи, Минск, Республика Беларусь

РУБРИКА ГРНТИ: 55.00.00 МАШИНОСТРОЕНИЕ:

55.49.03 Аэродинамика ракет и космических аппаратов ВИД СТАТЬИ: оригинальная научная статья

Резюме:

Ведение/цель: Проведен анализ сверхзвукового обтекания шара радиусом 1 м на высотах полета $80 \div 40$ км.

Методы: Траектория спуска при первой космической скорости использовалась та, которая соответствует аппарату «Союз» без теплозащиты с дюралюминиевой конструкцией.

Результаты: Для газа между фронтом ударной волны и поверхностью спускаемого аппарата получены данные по увеличению плотности, давления и температуры за фрронтом ударной волны, а также отхода ударной волны от поверхности спускаемого аппарата. Эфрфективная температура ударно нагретого газа достигает своего максимального значения $7340 \mathrm{~K}$ на высоте 60 км. На высотах полета 80 и 40 км эфорективная температура составляет соответственно $7000 \mathrm{~K} \mathrm{u} 6400 \mathrm{~K}$. Ha основании полученных данных о термодинамическом состоянии газа за ударной волной через каждых 10 км произведены расчеты потоков энергии на поверхность летательного аппарата при конвективном илучистом теплообмене, а также при ударном воздействии электронами, которые получены при ионизации отрицательных ионов. Лучистый теплообмен оказался наиболее существенным. Установлен механизм горения отрицательных ионов трехатомных молекул алюминия с образованием молекул AlO и получены данные по увеличению давления в пограничном слое у поверхности летательного аппарата. На всех рассмютренных высотах полета давление повышается меновенно до значения на

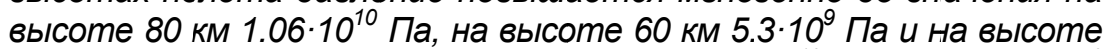


$\div 10^{10}$ Па возникают при подрыве разных взрывчатых веществ. Поток энергии на поверхность спускаемого аппарата поступает между взрывами. В момент взрыва у поверхности спускаемого аппарата возникают ударные волны в окружающей атмосфере и волны сжатия во всей конструкции летательного аппарата. Спускаемый аппарат растрескивается, $и$ вся конструкция аппарата распадается на отдельные части. Резко возрастает 
площадь взаимодействия, и каждый последовательный взрыв возрастает по своей мощности и соответственно в размерах. Последний самый мощный взрыв происходит на высоте 40 км, после которого на Землю падают отдельные обломки летательного аппарата.

Вывод: Освоение космического пространства с полетом на другие планеты возможно только при тщательном изучении взрывных процессов у поверхности спускаемого аппарата на других планетах, а особенно при спусках на планету Земля.

Ключевые слова: взрыв взрывчатых веществ, сверхзвуковое движение, конвективный теплообмен, лучистый теплобмен, эффректы потока электронов, отрицательные ионы.

ЕКСПЛОЗИЈА ГРАНИЧНОГ СЛОЈА ПО УЛАСКУ СВЕМИРСКЕ ЛЕТЕЛИЦЕ У ГУСТЕ СЛОЈЕВЕ ЗЕМЉИНЕ АТМОСФЕРЕ

Леонид И. Гречихин

Белоруска државна академија за комуникације,

Минск, Република Белорусија

ОБЛАСТ: машинство

ВРСТА ЧЛАНКА: оригинални научни рад

Сажетак:

Увод/циљ: Анализиран је суперсонични ток око сорере полупречника 1 м на висинама од 80 до 40 км.

Meтоде: Разматрана је силазна трајекторија при првој космичкој брзини, слична трајекторији свемирске летелице Сојуз с алуминијумском структуром без топлотне заштите.

Резултати: За гас између фронта ударног таласа и површине свемирске летелице при спуштању добијени су подаци о повећању густине, притиска и температуре иза фронта ударног таласа, као и о померању ударног таласа од површине свемирске летелице у фрази спуштања. Ефективна температура гаса загрејаног услед удара достиже максималну вредност од 7340 К на висини од 60 км. На висинама од 80 и 40 км ефективна температура је 7000 К, односно 6400 К. На основу података о термодинамичком стању гаса иза ударног таласа на сваких 10 км, израчунати су фрлуксеви енергије ка површини свемирске летелице за пренос топлоте конвекцијом и радијацијом, као и за утицај електрона насталих услед јонизације негативних јона. Показало се да је пренос топлоте радијацијом најзначајнији. Утврђен је механизам сагоревања негативних јона триатомских молекула алуминијума са форммиањем АIO молекула и добијени су подаци о

\section{1}


порасту притиска у граничном слоју на површини свемирске летелице. На разматраним висинама притисак тренутно расте


км и достиже максималну вредност од $5,5 \times 10^{10} \mathrm{~Pa}$ при висини од 40 км. Притисак од $10^{9}$ до $10^{10}$ ствара се током експлозија различитих типова експлозива. Флукс енергије стиже до површине свемирске летелице између експлозија. У тренутку експлозије ствварају се ударни таласи у атмосфрери око површине свемирске летелице која се спушта, а унутар њене целокупне структуре настају компресивни таласи. Свемирска летелица пуца при спуіштању, а целокупна структура се распада. Убрзано се повећава област интеракције и свака наредна експлозија је снажнија и већа. Последња најинтензивнија експлозија настаје на висини од отприлике 40 км, праћена падом фрагмената свемирске летелице на Земљу.

Закључак: Истраживање свемира путем летова на друге планете могуће је само после исирпног проучавања експлозивних процеса који се дешавају на површини свемирске летелице при спуштању на другу планету, а нарочито при спуштању на Земљу.

Кључне речи: експлозија експлозива, суперсонично кретање, пренос топлоте конвекцијом, пренос топлоте радијацијом, ефректи фрлукса електрона, негативни јони.

Paper received on / Дата получения работы / Датум пријема чланка: 29. 09. 2020.

Manuscript corrections submitted on / Дата получения исправленной версии работы / Датум достављања исправки рукописа: 17. 10. 2020.

Paper accepted for publishingon / Дата окончательного согласования работы / Датум коначног прихватања чланка за објављивање: 19. 10. 2020.

( 2020 The Author. Published by Vojnotehnički glasnik / Military Technical Courier (www.vtg.mod.gov.rs, втг.мо.упр.срб). This article is an open access article distributed under the terms and conditions of the Creative Commons Attribution license (http://creativecommons.org/licenses/by/3.0/rs/).

(C) 2020 Авторы. Опубликовано в «Военно-техническийвестник / Vojnotehničkiglasnik / Military Technical Courier» (www.vtg.mod.gov.rs, втг.мо.упр.срб). Данная статья в открытом доступе и распространяется в соответствии с лицензией «Creative Commons» (http://creativecommons.org/licenses/by/3.0/rs/).

( 2020 Аутори. Објавио Војнотехнички гласник / Vojnotehničkiglasnik / MilitaryTechnical Courier (www.vtg.mod.gov.rs, втг.мо.упр.срб). Ово је чланак отвореног приступа и дистрибуира се у складу са Creative Commons лиценцом (http://creativecommons.org/licenses/by/3.0/rs/).

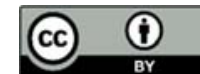

